\title{
TRATAMENTUL CIROZEI HEPATICE CU VIRUS HEPATITIC C, CU INTERFERON PEGYLAT- RIBAVIRINĂ ŞI INTERFERON FREE - STUDIU COMPARATIV
}

\author{
S.A. Florescu, S. Lazăr, C. Oprea, A. Moțoc, D. Codreanu, A.G. Kosa, E. Ceauşu \\ Grupul de lucru proiect PN II PT PCCA 88/2011
}

\begin{abstract}
REZUMAT
Articolul descrie comparativ efectele adverse şi eficienţa tratamentelor disponibile prin Casa Naţională de Asigurări de Sănătate (CNAS) pentru hepatita cronică de tip $C$, pe o populaţie de pacienţi monitorizată în Spitalul Clinic de Boli Infecţioase şi Tropicale „Dr.V. Babeş“, în perioada 2012-2016. Populaţia a fost împărţită în două loturi pentru care s-a realizat înregistrarea caracteristicilor demografice şi clinico-paraclinice în baza de date, precum şi o analiză comparativă. S-a constatat un succes evident în privinţa atingerii indicatorului clinic SVR pentru terapia de tip DAA, $87 \%$ în lotul B comparativ cu $2 \%$ pentru vechiul standard Peglnterferon + Ribavirin, în lotul A. De asemenea, ponderea efectelor adverse este mult scăzută la lotul B faţă de lotul A. Rămân anumite efecte adverse - specifice tratamentului CNAS actual pentru pacienţii cu ciroză, care trebuiesc monitorizate cu atenţie.
\end{abstract}

Cuvinte cheie: hepatita cu virus $C$, antivirale cu acţiune directă (DAA), răspuns virologic susţinut (SVR)

\section{INTRODUCERE}

Hepatita datorată infecției cu virus de tip C este o boală cu impact major asupra sănătății organismului uman. Într-un interval variind de la câțiva ani până la zeci de ani, bolnavul poate dezvolta complicații ca urmare a cronicizării bolii - cum ar fi ciroză hepatică sau carcinom hepatocelular (1). Boala poate să fie accelerată de consumul de droguri, coinfecția cu HIV sau cu virusul hepatitic B (2). Hepatita cu virus C este o problemă de sănătate publică, la nivel global fiind înregistrați peste 170 de milioane de oameni infectați.

La ora actuală nu există vaccin contra virusului hepatitei C (HCV), iar dezvoltarea unuia în viitorul apropiat este puțin probabilă, din cauza multitudinii de provocări, dintre care cea mai importantă este diversitatea extremă a virusului care prezintă o divergență de peste $30 \%$, la nivel de aminoacizi, pentru cele 7 genotipuri majore (3).

Pentru ca tratamentul să fie de succes, se urmărește atât eliminarea totală a virusului (clearance viral), cât și îmbunătățirea stării clinice. Unul din indiciile cele mai folosite pentru confirmarea unui tratament de succes este răspunsul virusologic susținut (sustained virological response sau SVR), care înseamnă lipsa ARN-ului virusului C în sânge, după terminarea tratamentului. Atingerea SVR se corelează cu un tablou clinic îmbunătățit și implicit cu scăderea mortalității. 


\section{Scurt istoric al tratamentului pentru hepatită cu virus $\mathrm{C}$}

După identificarea în 1989 a virusului responsabil pentru hepatita $C$, în mod independent de către CDC (Center for Diseases Control) și compania CHIRON, primul medicament aprobat a fost interferonul alfa-2B în anul 1991, un medicament care interferă cu replicarea virală printr-un mecanism care implică răspunsul imun al organismului. În anul 1998 a fost aprobată combinația între interferon și ribavirină (analog ribonucleic folosit ca inhibitor nucleozidic), urmând ca în 2001 să fie introdus interferonul pegylat (Peginterferon). A urmat o perioadă de cercetări intense în industria farmaceutică și în mediul academic pentru descoperirea unor molecule cu efect antiviral direct împotriva virusului C, independent de răspunsul imun al organismului - fără aportul imunomodulatorului inteferon, substanță care produce o multitudine de efecte adverse, în parte răspunzătoare de eșecul terapeutic al acestei variante de tratament (Fig. 1).

\section{9 identificarea virusului C

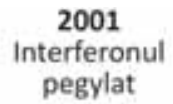

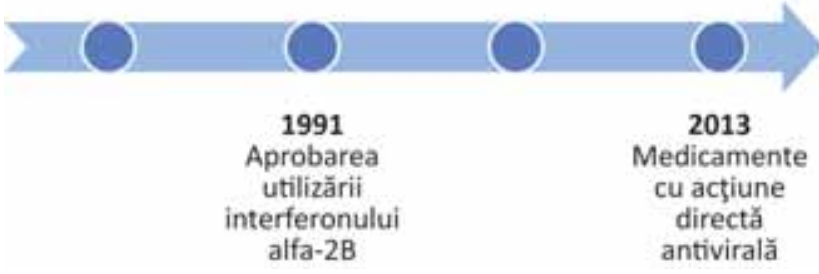

Figura 1. Evoluţia istorică a strategiilor de tratament a hepatitei $C$

De-a lungul acestei evoluții, eficiența tratamentului, reprezentată prin rata SVR, a variat de la 30\% în cazul interferonului alfa-2B, 65\% în cazul interferonului combinat cu ribavirină, până la maxim $75 \%$ pentru interferonul pegylat combinat cu ribavirină $(1,4)$.

Începând cu 2013, au devenit disponibile substanțele cu acțiune directă antivirală - direct acting antiviral-DAA, care, în diferite combinații, sunt între $84 \%$ și 95\% eficiente pentru tratamentul infecției cronice VHC între 84\% și 95\% (1,4), întrun timp mai scurt și fără efecte adverse notabile, mai ales dacă termenul de comparație este standardul PegInterferon + Ribavirin. În anul 2015, $\mathrm{au}$ fost introduse medicamentele cu acțiune directă antivirală și în România, în cadrul programelor rambursate de Casa Națională de Asigurări de Sănătate (CNAS), acestea fiind decontate numai pentru pacienții infectați cu virus $C$ aflați în stadiul de ciroză hepatică (scor fibroză F4). Această variantă terapeutică (Interferon-free) presupune asocierea dintre VIEKIRAX ${ }^{\circledR}(\mathrm{Ombitasvirum}$ + Paritapresvirum + Ritonavirum) și EXVIERA ${ }^{\circledR}$ (Dasabuvirum), la care se adaugă sau nu RIBAVIRINA.

\section{MATERIALE ŞI METODE}

În perioada 2011-2016 s-a desfășurat în Spitalul Clinic de Boli Infecțioase și Tropicale „Dr. Victor Babeș“ - București (SVB) un proiect de cercetare (PN II PT PCCA 88-2011), coordonat de Institutul Național de Cercetare Cantacuzino și în parteneriat cu Institutul Clinic Fundeni, Institutul Național de Virusologie Ștefan S. Nicolau și Personal Genetics SA, în scopul optimizării tratamentului standard la momentul respectiv, pentru pacienți infectaţi cronic cu VHC. Proiectul a vizat depistarea markerilor genetici de rezistență la tratamentul cu PegInterferon și Ribavirin, pentru elaborarea unui algoritm de optimizare a indicației la tratament, având în vedere numeroasele efecte adverse ale acestuia și impactul major asupra calității vieții pacientului. În SVB s-a creat o bază de date cu 190 de pacienți tratați și monitorizați în perioada 2012-2014 privind răspunsul la tratament și efectele adverse.

Derularea proiectului de cercetare a avut o suprapunere temporală peste perioada de cercetare și intrare în practica curentă a DAA. În acest sens, folosind cercetările efectuate în cadrul proiectului, am efectuat un studiu comparativ asupra celor două tipuri de tratament aplicabil categoriei de pacienți cu hepatită cronică C aflați în stadiul de fibroză F4. 
Acesta este un studiu observațional retrospectiv asupra a două populații de pacienți tratați și monitorizați în perioada 2012-2016. Criteriile de includere în studiu au fost: stadiul de fibroză hepatică F4, măsurat prin proceduri agreate de Casa Națională de Asigurări de Sănătate (Fibroscan ${ }^{\circledR}$ respectiv Fibroscore ${ }^{\circledR}$ ), tratament cu PegInterferon și Ribavirin (populația din lotul A), respectiv tratament cu DAA (populația din lotul B). Criteriul de eficiență a tratamentului aplicat a fost rata de SVR atinsă în fiecare din cele două loturi. La acest criteriu s-a adăugat procentul de reacții adverse asociat tratamentului instituit. Colectarea datelor, prelucrarea lor și executarea graficelor s-a făcut în programul Excel v.2010.

\section{REZULTATE ŞI DISCUŢII}

Numărul de pacienți aflați în stadiul F4 tratați cu PegInterferon și Ribavirină a fost de 24 într-o perioadă de 2 ani (2012-2014), iar numărul de pacienți tratați cu DAA a fost de 89, pe o perioadă de 1 an (2015-2016).

Media de vârstă a fost apropiată, de aprox 57 de ani în lotul A față de aproximativ 61 de ani în lotul B (Fig. 2). Raportul sexelor a fost relativ echilibrat, $42 \%$ femei față de $58 \%$ bărbați în ambele loturi (Fig. 3,4).

În privința viremiei nedetectabile măsurate la sfârșitul perioadei de tratament și post tratament, s-au înregistrat 8\% (2 pacienți) cu SVR în lotul A, respectiv 98\% (87 pacienți) în lotul B (Tabel 1).

În privința reacțiilor adverse hematologice s-a observat o rată foarte mică în cadrul lotului B

Tabelul 1. Aspecte comparative între cele două loturi de pacienţi aflaţi în stadiul F4

\begin{tabular}{|l|l|l|}
\hline Caracteristică & $\begin{array}{l}\text { Lotul A } \\
\text { (n=24) }\end{array}$ & $\begin{array}{l}\text { Lotul B } \\
\text { (n=89) }\end{array}$ \\
\hline Media de vârstă (ani) & 56,8 & 60,6 \\
\hline Gen (B/ F) & $14 / 10$ & $52 / 37$ \\
\hline $\begin{array}{l}\text { Viremie nedetectabilă la sfârșitul } \\
\text { tratamentului }\end{array}$ & $2(8 \%)$ & $87(98 \%)$ \\
\hline Reacții adverse hematologice & & \\
\hline Neutropenie & $19(79 \%)$ & $0(0 \%)$ \\
\hline Trombocitopenie & $11(46 \%)$ & $0(0 \%)$ \\
\hline Anemie & $20(83 \%)$ & $18(20 \%)$ \\
\hline
\end{tabular}

spre deosebire de numărul mare al acestor reacții în lotul A (Tabelul 1) (Fig. 5).

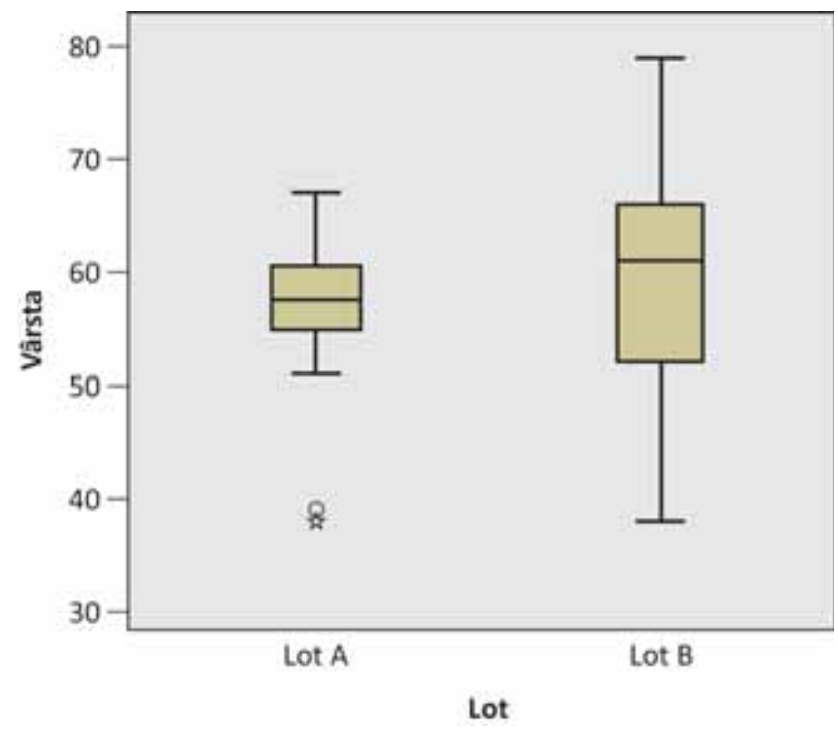

Figura 2. Media vârstelor în cele două loturi

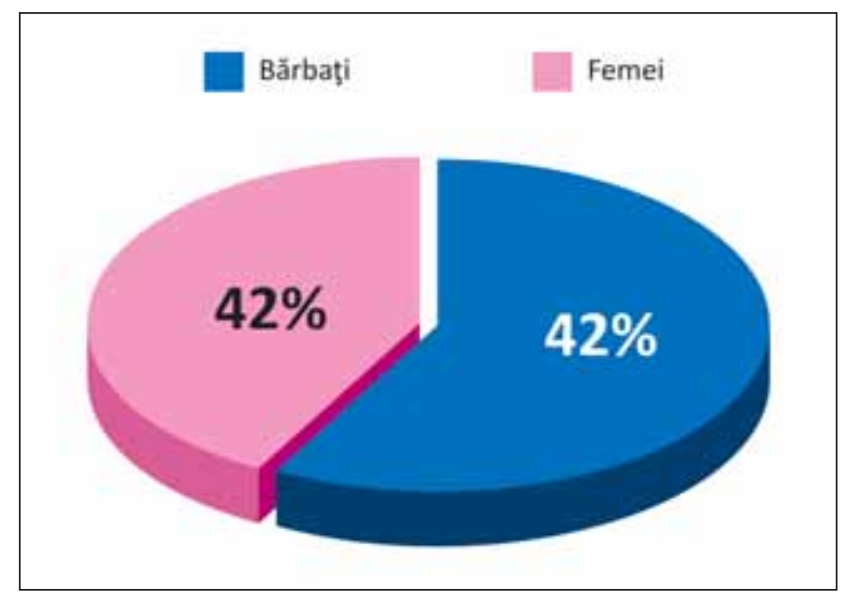

Figura 3. Distribuţia pe sexe în lotul A

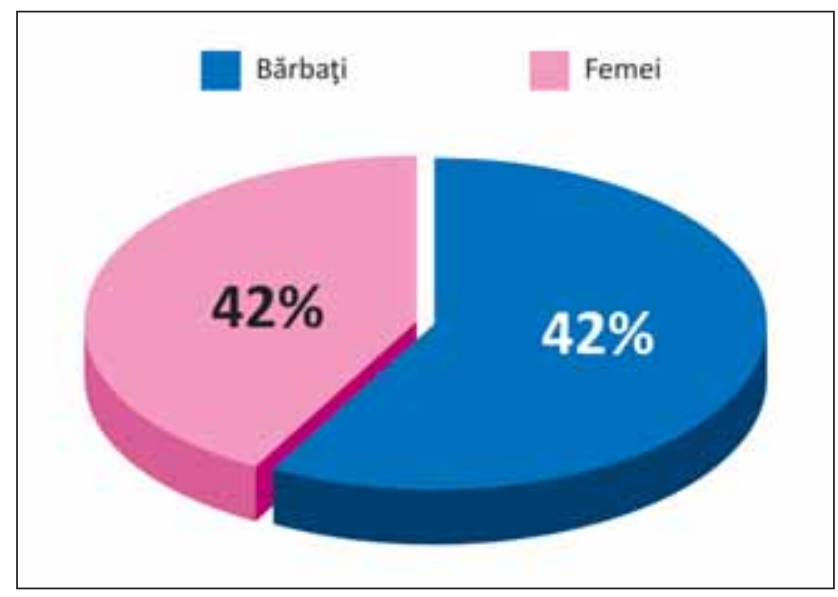

Figura 4. Distribuţia pe sexe în lotul B 


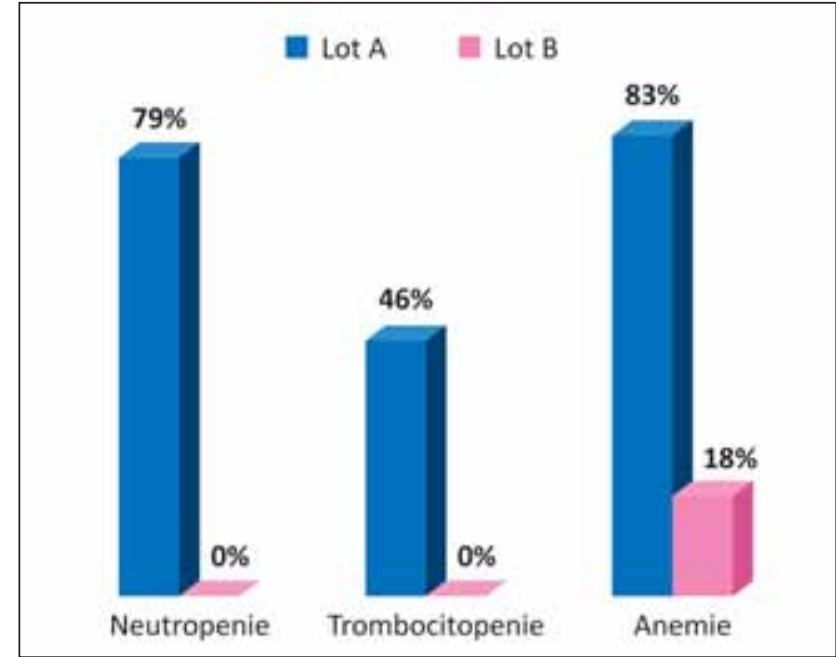

Figura 5. Procentele de apariţie a efectelor adverse în cele două loturi

În afara reacțiilor adverse hematologice, s-au mai înregistrat:

\section{- În cadrul lotului A:}

- Astenie (67\%);

- Depresie și alte tulburări ale statusului psiho-social al pacientului (58\%);

- Tiroidită cu hipo/hipertiroidism (36\%);

- Scăderi în greutate și tulburarea apetitului alimentar (79\%).

- În cadrul lotului B:

- Astenie (28\%);

- Depresie (17\%);
- $\operatorname{Icter}(4 \%)$;

- Insuficiență renală acută (1\%) cu hemodializă și întreruperea tratamentului;

- Deces $1 \%$.

\section{CONCLUZII}

1. Tratamentul Interferon-free are eficacitate net superioară tratamentului cu PegInterferon și Ribavirin - aspect evidențiat aici la categoria de populație infectată VHC cu fibroză hepatică stadiul 4;

2. Efectele adverse au fost mult mai puține ca tip și frecvență în cadrul lotului B (DAA) față de lotul A;

3. Introducerea protocolului terapeutic pe bază de DAA pentru pacienții cu ciroză hepatică VHC-fibroza F4 a permis acestei categorii de pacienți accesul la tratament într-un număr mai mare, prin scăderea perioadei de tratament și a efectelor adverse.

4. Efectele adverse specifice DAA - medicație cu un istoric scurt de folosire la pacienți, necesită supravegherea atentă a subpopulației cu ciroză, în timpul și după cele 3 luni de tratament. 